\title{
One or two nation projects? Discourse on inequalities and equality-related policies in South Africa and Brazil
}

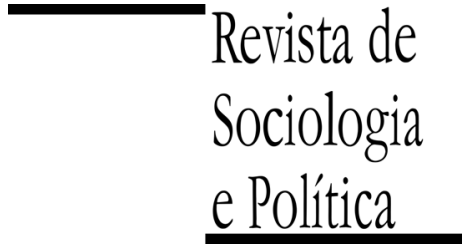

DOI 10.1590/1678-987315235503

\section{Bernhard Leubolt}

\begin{abstract}
This contribution focuses on the social production and reproduction of social inequalities in Brazil and South Africa. It aims at interlinking different theoretical perspectives and applying them to a comparative analysis of inequality-related policies. Resorting to strategic-relational institutionalism, the historical heritage of discourse formation and the institutionalization of inequality regimes in the two countries to inform the analysis of the more recent conjuncture will be analysed. While South Africa is an example of formal racist discrimination, the Brazilian inequality regime worked on more informal patterns. The different historical heritage influences current foci of equality-related policies, which tend to be dominantly anti-racist in South Africa, while focusing on poverty reduction in Brazil during the recent years. The latter experience tended more towards a discourse of a 'common interest' and was better able to institutionalize policies to reduce income inequalities. South Africa is still discursively divided into 'two nations'. Social uplifting for Africans linked to the governing parties was only partially accompanied by improved living conditions for the poor majority of Africans. Both countries are significantly structured by the respective historical heritage concerning both the creation and the reduction of inequalities. The Brazilian 'one nation' discourse was more successful in promoting equality-related policies than its 'two nations' counterpart in South Africa. Despite important improvements, both countries are now in critical junctures and societal contradictions are beginning to create new crisis tendencies.
\end{abstract}

KEYWORDS: Brazil; South Africa; inequality; historical institutionalism; social policies.

Recebido em 11 de Outubro de 2014. Aceito em 22 de Fevereiro de 2015.

\section{Introduction ${ }^{1}$}

\footnotetext{
1 The author would like to thank Andreas Novy, Christoph Scherrer, Joachim Becker, Karin Fischer, Lauro Matei, and the anonymous reviewers of the Revista de Sociologia e Politica for their useful comments on this article.

2 This contribution was written within the International Research Project 'Combating Inequality - Causes of economic and social inequality', organized by the International Center for Development and Decent Work and financed by the Hans Böckler Foundation.

3 The literature on different and intersecting forms of inequalities (e.g. Andersen \& Hill Collins 2003; Walby 2009) would suggest to include at least the further dimension of
}

T his contribution focuses on the social production and reproduction of social inequalities, aiming at interlinking different theoretical perspectives $^{2}$. In the terms of the dimensions introduced by Lamont, Beljean and Clair (2014), it focuses on material, symbolic and cultural inequalities. While the former two forms rather focus on the macro-level and deeply rooted (structural) forms of inequalities, cultural processes of identification and rationalization center on complex linkages between dominant and subordinate actors. Lamont et al. (idem) criticize a latent determinism in analyses of material and symbolic inequalities which might be avoided by cultural approaches focusing on the micro-level. Without going much into detail on this discussion, this contribution is departing from a macro-level historical institutionalist perspective (Mahoney \& Rueschemeyer 2003) and attempts to link the dimensions of material, symbolic and cultural inequalities. Differing from individualistic perspectives, this contribution focuses on horizontal inequalities (Stewart 2002): the formation of collective identities, based on class, race and ethnicity, and the respective material, symbolic and cultural inequalities, will be the point of departure ${ }^{3}$.

Thereby, shortcomings in the existing comparative historical institutionalist literature on Brazil and South Africa will be addressed: the widely proliferated work of Anthony W. Marx (2006) focuses on the question of racial identities and racism in Brazil, South Africa and the US. Due to the 'myth of racial de- 
mocracy' in Brazil (to be shortly described afterwards), perspectives for antiracist policies are described as far more difficult than in South Africa. While generally agreeing with Marx's analysis, this contribution further highlights the question of redistribution, being fundamentally linked to issues of class inequalities and poverty. The latter issues have been dealt with by Lieberman (2001) in his comparison of Brazilian and South African tax policies. Focusing on the formation of different 'National Political Communities' (NPCs), Lieberman argues that South African 'elites' agreed to form a comparably united NPC, while Brazilian 'elites' did not succeed in obtaining a comparable unity among themselves. Lieberman argues that this resulted in differing ways in which race and class were addressed in the 1891 Brazilian constitution and the 1909 South Africa Act, which in turn affected the willingness of upper-income groups to accept state demands for income tax payments. He concludes that 'low-income blacks in South Africa benefit from the progressive income tax that was developed in the wake of this history of deliberate racial exclusion. By contrast, their poor, black Brazilian counterparts continue to face a far more regressive tax system' (idem, p.547). While Marx focuses on racism, Lieberman includes questions of class and social status. Nevertheless, his focus is mostly on 'elites' and the most formal political institutions. Identity formation of the marginalized groups remains opaque and institutions beyond the constitutions are only marginally considered.

Both authors argue that the historical-institutional heritage of the two countries favor equality-related policies in South Africa. More recent empirical findings do not support this point of view: South African indicators showed rising income inequalities since the end of apartheid (1994), from 0.66 in 1993 to 0.7 in 2000 (Leibbrandt et al., 2010, p.32), peaking at 0.72 in 2006, after which the Gini coefficient dropped slightly to 0.7 in 2009 and 0.69 in 2011 (SSA 2014, p.14). While general inequalities were rising, intra-racial inequalities dropped slightly (Seekings \& Nattrass 2005). In Brazil, the picture differed significantly: while intra-racial inequalities also dropped slightly, general inequalities dropped significantly, especially in the 2000s: after slight declines during the 1990s (the Gini dropping from 0.6 in 1993 to 0.59 in 1999), the Gini coefficient constantly improved during the 2000s, to 0.56 in 2006 with further drops to 0.54 in 2009 and 0.53 in 2011 and 2012 (IPEA 2015). As both countries have been governed by parties linked to the trade union movement and devoted to the reduction of inequalities, it is of special interest why income inequalities have been reduced to a much greater degree in Brazil than in South Africa ${ }^{4}$.

\section{Methodology: Strategic-Relational Institutionalism}

${ }^{4}$ A more nuanced discussion of indicators of inequality, poverty and wellbeing is beyond the scope of this article. It is important to note, that South Africa has witnessed fierce debates about the quality and validity of inequality indicators during the 2000 s (cf. Meth 2008).
This article does not engage in a quantitative impact analysis, but rather follows a similar path to Marx's (2006) and Lieberman's (2001) historical institutionalist accounts. Differing from Marx, it goes beyond the issue of racism and engages with a wider range of equality-oriented policies (Graser 2009) - mainly combining a power-distributional approach towards the political economy and social policies (Leubolt 2013, inspired by Esping-Andersen 1990) with an analysis of affirmative action policies. The approach towards the cultural dimension will be similar to Lieberman's account of the National Political Community (Lieberman 2001), but differing in the aspect of the considered identities which will go beyond the 'elite-community', but will also consider subaltern identities. To limit the scope of the article, not all subaltern identities will be focused. In line with the literature, the vertical dimension of inequalities will focus on the interplay of race and class (Hamilton et al., 2001). The dealing with the question of culture is guided by the ASID-approach (Moulaert \& Jessop 2013; Novy et al., 2013) and the strategic-relational approach (Jessop 2007) with important inspirations by the Latin American traditions of 
5 The main focus of this contribution will be on discourse. More in-depth institutional analyses have been published elsewhere (Leubolt 2013; 2014a; 2014b; 2015). Their explicit consideration would go beyond the scope of a single article. structuralism (Cardoso \& Faletto 1979; Furtado 2007) and conjunctural analysis (Fiori 1995; Souza 2002).

The thereby resulting approach will be labeled here as 'strategic-relational institutionalism': the historical roots of discursive constructions of inequality and equality will be considered in respect to their influences on the (in)equality-related institutions ${ }^{5}$. The analysis of the historical heritage will be guided by periodization: methodologically, periodization will be employed to sequence historical events viewed as essential for the structuring of inequality regimes in Brazil and South Africa. Differing from a chronology, which orders actions, events or periods on a single unilinear time scale, a periodization operates with several time scales, resulting in differing conjunctures for the actions of the involved social forces with decisive turning points, marked by crises (Jessop 2002).

Two different forms of periodization will be employed: the historical roots of the production and reproduction of inequalities will be traced back by a periodization similar to the longue durée employed by the Annales-school of historical writing. The version employed in this article is mainly influenced by Latin American structuralism (Cardoso \& Faletto 1979; Furtado 2007) and the regulation approach (Boyer \& Saillard 1995). It will distinguish larger periods of relatively stable patterns of development, which are divided by profound economic, political and cultural crises. These crises are understood as important periods of rupture, which are opening new paths, albeit 'path dependencies' (Ghezzi \& Mingione 2007, chapter 3) still remain, as important features of the periods before the crises remain in the new periods. The historical periods identified in chapter 3 will serve as a framework for a more fine-tuned periodization presented in the preceding chapters. Influenced by theoretical currents succeeding Marx's '18 ${ }^{\text {th }}$ Brumaire', such as Jessop (2002), the Latin American tradition of conjunctural analysis (Fiori 1995; Souza 2002) and the South African Poulantzian (Poulantzas 1974) current of periodization (Davies et al., 1976; Wolpe 1990), the situation since the establishment of democracies will be analyzed. Similar to the approaches presented by Fiori (1995) and Cardoso and Faletto (1979), the primary focus will be on the national contexts of Brazil and South Africa, with brief acknowledgement of their insertion into the global political economy. By exploring the historical roots of the inequality regimes and equality-oriented discourses, the context-specifics of the two analyzed cases will be uncovered.

Special emphasis will be given to the notion of 'one-nation' and 'two-nations-projects': Disraeli (2010) originally developed the notion of 'two nations' in 1845 for the analysis of British Victorian politics. His description of the situation of the British working class of these times can easily be used for the state of marginalization and exclusion of large parts of the population until today (Enriques 2007). In Disraeli's novel, a central character states "that an impassable gulf divided the Rich from the Poor; I was told that the Privileged and the People formed Two Nations, governed by different laws, influenced by different manners, with no thoughts or sympathies in common; with an innate inability of mutual comprehension". The resulting exclusionary state project has been termed a 'two-nations project' by Jessop et al. (1988) in their analysis of Thatcherism and has already been applied to the cases of South Africa (Ansell 2004; Nattrass \& Seekings 2001) and Brazil (Leubolt 2013). In contrast, a 'one-nation project' would envision a more universal notion of 'social citizenship' (Marshall 1950), avoiding exclusion by promoting universalizing cultural, political and social rights. This analysis will distinguish between a universalizing discourse and actually existing institutions to better capture the difference between formal and informal exclusion in South Africa and Brazil. 


\section{Similar inequalities, differing historical roots}

South Africa and Brazil are both marked by comparably high rates of inequalities which have a strong racial connotation, linked to influences of colonialism (Hall \& Gay 1996). Nevertheless, colonial influences were institutionalized differently: throughout the colonial history of both countries, mainly Africans had to do the hard physical labor. While they were shipped to Brazil as slaves from the $16^{\text {th }}$ century until the end of the $19^{\text {th }}$ century, the patterns of labor exploitation were different in South Africa: the Dutch colonizers established a system of settler colonialism, which resulted in (often violent) land conflicts, but resorted to African labor power to a much lesser degree than the Brazilian slavery-based economy. Therefore, inter-racial relationships in South Africa have always been much more distant and racial differences hardly ever began to blur, as it happened in Brazil, where a peculiar system of informal hierarchies differentiated slaves and their owners, who lived in close proximity, but nevertheless clearly distinguished from each other (Freyre 1992; Marx 2006).

In contrast, the roots of the apartheid system of institutionalized racism and racial separation can be traced back to settler colonialism, where the Dutch viewed themselves as 'the white tribe of Africa' and clearly separated from other African tribes (Louw 2004). Capitalism began to develop dynamically after gold was found in the mid- $19^{\text {th }}$ century. Mining capital was predominantly British. New ethnic hierarchies began to form, as the British established themselves as hegemonic group, while the Dutch were lagging behind and increasingly proletarized. Land conflicts between these groups further fuelled the tensions which led to the Anglo-Boer Wars by the end of the $19^{\text {th }}$ century. The British won the second decisive war and began to construct a state geared to serve the interests of mining capital, which primarily needed cheap supply of labor and land (Louw 2004; Terreblanche 2002). The loss of land ownership fuelled a process of proletarization of both Dutch and Africans. The latter were further forced by legislation to work as migrant workers to ensure a constant inflow of relatively cheap labor supply (Wolpe 1980) ${ }^{6}$. The Dutch resisted this treatment and searched for unity on the bases of both class and race. Dutch rebellion culminated in the Rand revolt in 1922, when a general strike led by Dutch-dominated workers' organizations (under the slogan 'workers unite for a white South Africa') paralyzed the country. To maintain political stability of colonial rule, the British began to integrate important Dutch political leaders into government and began to implement racist social and labor market policies in favor of the Dutch. Race thereby became the central political category for creating unity in the power bloc (Beinart 2001). Exclusion was carried out on a formal basis, fostering a racist discourse of a 'two nations project', separating 'black' and 'white' (Leubolt 2009). Inclusion was mainly concerned with the ethnic minority of the Dutch to be socially uplifted to the standards of the British. The main institutional channels for this uplifting were affirmative action policies in the public sector combined with the amplification of state activities (Louw 2004). Thereby, class tensions within the two colonizing groups were minimized to the detriment of the remaining groups, for whom class domination and racism became intertwined (Wolpe 1990).

The racist 'two nations project' was further radicalized under apartheid (1948-1994) and officially re-formulated into a 'many nations project'. Following Machiavelli's guideline of 'divide and conquer', the apartheid regime followed an ideology of 'separateness' (apartheid) of different 'tribes' while fortifying racism: they tried to separate Africans along ethnic criteria, while fostering policies to promote the Dutch vis á vis the British on the labor market (Louw 2004). The constant aggravation of racism promoted the anti-apartheid movement to grow stronger. The African National Congress had started off as a 
rather small movement of middle class Africans trying to promote their position in the labor market. Under apartheid, it joined forces with the South African Communist Party (SACP) and thereby shifted to the left. Nevertheless, the strong unifying category was 'race', as freedom fighters categorized themselves as 'black' - resisting the different racial and ethnic division criteria introduced by the apartheid regime. The main target of their fight was institutionalized racism, albeit with different foci: liberals viewed racism as detrimental to capitalism, while socialists saw it as symbiotic; multiracialists wanted to abandon racism, while Africanists wanted African supremacy. Common sense was the demand for majority vote, regardless of race (Alexander 2002). Thus, not only the regime, but also its main critics, organized around the notion of race.

In contrast, Brazilian capitalism could only develop as slavery was gradually abandoned throughout the $19^{\text {th }}$ century. Despite the abolition of slavery, most former slaves never had a chance to integrate into the newly emerging capitalist society and remained excluded, while European migration was promoted to cope with labor shortages. Thereby, informal hierarchies and forms of social exclusion were promoted and also politically institutionalized. The state emerging out of this scenario has been characterized as 'patrimonial' (Faoro 2001), as personalism and paternalism were decisive (opposed to impersonal rightsbased bureaucratic procedures; cf. Weber 1980). In 1930, a coup d'état directed by Getúlio Vargas countered patrimonialism and established a way of governing which was later described as 'populism' (Ferreira 2001; Weffort 1978): marginalization continued to be a process affecting large groups of the population, who had to work in the informal labor market. Thereby they were never granted the same rights as the formal workers, who began to be granted social and labor rights under Vargas, especially since the introduction of the minimum wage and the Consolidação das Leis do Trabalho between the end of the 1930s and the beginning of the 1940s. This resulted in a division of workers, as the majority had to continue working in informal settlements, mostly on the countryside, whilst the minority of mostly urbanized workers in the formal sector began to be included. While a new utopia of 'cidadania' emerged, the unequal institutionalization and societal structure remained. Vargas' alliance with the traditional 'elites' impeded further steps (Cardoso 2010). Contrary to South Africa, a 'one-nation project' was envisioned, but not institutionalized as informalization turned into the main dividing line between the included and the excluded parts of the population (Leubolt 2013).

From the 1930s onwards, 'developmentalism' became the dominating discourse in Brazil, whereby development was equated with industrialization and capitalist development. Liberal, conservative and 'populist' versions of this discourse differed in many aspects, but all viewed the state as the organizer of this sort of development. Inequalities were largely covered by a 'discourse of non-existing violence' (Chaui 1995), projecting harmony between the rich and the poor and the non-existence of racism (Freyre 1992; Marx 2006). Therefore, little importance was attached to the reduction of inequalities, except for some developmentalist currents: 'populists' were in favor of including the formal sector of the working class via workers' and social rights to prevent them from striking and to promote social stability. More radical developmentalist currents linked to the dependency school and/or socialism argued for a more thorough inclusion of the hitherto marginalized. In their view, Brazilian inequalities hindered the country to develop similar as European countries or the US, as a mass market would never be able to develop thoroughly (Furtado 1963; Tavares 2000). Contrary to South Africa, the dominant discourse projected a 'one nation project' of national unity with differences concerning the perception of the actual situation. 
${ }^{7}$ Gelb (1991) identified the respective period as 'racial Fordism'. For the sake of this paper, it seems to be more appropriate to slightly modify Gelb's original idea to better reflect the racist character of the period.
Table 1 shows the periodization of the developments sketched out above concerning South Africa, while Table 2, below, focuses on Brazil. In South Africa, capitalism began to emerge out of 'settler colonialism'. It was linked to gold mining and represented an ethnically differentiated capitalism with the British on top of the hierarchy. Tensions were most strongly voiced by the Dutch labor movement, resulting in the establishment of 'racist Fordism'? 'Racist Fordism' was further radicalized by the apartheid regime which features important continuities to the patterns of 'racist Fordism'. By the end of the 1960s, 'racist Fordism' began to show symptoms of an economic crisis, as the racist regulation of the labor market became more and more dysfunctional. Mechanization in the still dominant mining sector demanded less unskilled but more skilled and semi-skilled workers. As a result, liberal voices criticizing the economic dysfunctionalities gained momentum - not only within the freedom movement, but also within the power bloc, where critical voices by capitalists grew stronger. Combined with increased international critique and economic sanctions, this weakened the apartheid regime, which initiated the transition to a non-racist regime, reacting to these critics and the pressure of the freedom fighters, who continuously intensified their struggle from the 1970s onwards. Despite these favorable conditions for the progressive movement, the transition to the post-apartheid regime was also marked by advantages for the adherents of the apartheid regime. A very important factor in this respect was violence enacted by security forces and allies of the regime against Africans in the townships. Therefore, Marais (2011, p.58ff.) diagnoses a 'stalemate' between the ANC-led freedom fighters and the apartheid regime. Although the transformation to a non-racist regime began in the 1970s, it only gained substance with the first general non-racist elections in 1994.

In contrast to apartheid in South Africa, the military dictatorship is usually not given the same importance concerning Brazil's periodization. Nevertheless, a more fine-tuned periodization highlights the importance of the military dicta-

Table 1 - Periodization, South Africa, from 17th century onwards

\begin{tabular}{ll}
\hline Period & Phases \\
\hline $1652-1890$ & 'settler colonialism' \\
$1890-1923$ & Ethnically differentiated capitalism \\
$1924-1970$ s & 'racist Fordism' \\
$1948-1994$ & Apartheid Regime \\
Since 1970s & Transformation to 'non-racist capitalism' \\
Since 1994 & Post-Apartheid Regime \\
\hline
\end{tabular}

Source: The author.

Table 2 - Periodization, Brazil, from 16th century onwards

\begin{tabular}{ll}
\hline Period & Phases \\
\hline $1500-1850$ & Slavery-based patrimonialism \\
$1850-1929$ & 'Estate-based capitalism' [capitalismo baseado em estamentos] \\
$1930-1982$ & $\begin{array}{l}\text { Developmentalism } \\
1982-2006\end{array}$ \\
& $\begin{array}{l}\text { Democratization and social reforms being counteracted by } \\
\text { neoliberal reforms, resulting in 'inclusive liberalism' }\end{array}$ \\
$2007-2014$ & New Developmentalism \\
\hline
\end{tabular}

Source: The author. 
torship that put an end to more radical equality-oriented politics originating out of 'populism', aiming at the inclusion of the hitherto marginalized (Ferreira \& Delgado 2003; 2008). Important critical junctures in the period of 'populism' can be detected in 1954, when Vargas committed suicide to prevent the country of a military coup d'état. This happened at a conjuncture of radicalization of the 'populist' project, at the period when the minimum wage reached one of its historic peaks in real wage terms (cf. Graphic 1). The radicalization in the beginning of the 1960s culminated in the proposals for 'reformas de base' under president Goulart, which substantially included the hitherto marginalized for the first time through proposals for a land reform. In the international context of the cold war, the middle classes were mobilized against the alleged 'communism' stemming from the reforms and then largely supported the military coup in 1964. Under the military dictatorship, the trend to implement more radical equality-related policies was stopped, which is reflected in the drop and subsequent stagnation of the minimum wage from 1964 onwards (cf. Chart 1).

From the end of the 1970s onwards, symptoms of a deep economic crisis began to be visible and fuelled opposition to the regime. Besides the official opposition party, an autonomous and combative trade union movement (led by Luiz Inácio Lula da Silva) emerged and proved to be a decisive force against the regime. Protests were geared against both authoritarianism and inequalities (especially concerning access and quality of public services and infrastructure). The 1980 s can be seen as the time of a deep 'organic' crisis, as economic, social, political and cultural crises of the Brazilian state were interlinked. Therefore the critical juncture resulted in profound changes on the economic and political spheres that led to an end of the first period of developmentalism (Table 3).

The protests against the military dictatorship finally culminated in the participatory drafting of a constitution that was finally ratified in 1988. Even though the constitution included conservative claims against a thorough land reform, it also featured progressive claims, mainly in the field of social policies. A discourse of 'social citizenship' (cidadanía, cf. Dagnino 1994) was decisive in this regard, linking the claims for democracy and social justice. Institutionally, its main impact was on the development of social policies: several social rights were universalized - especially visible by the introduction of the Sistema Único

Chart 1 - Minimium wages, $\mathrm{R} \$$ values (2014)

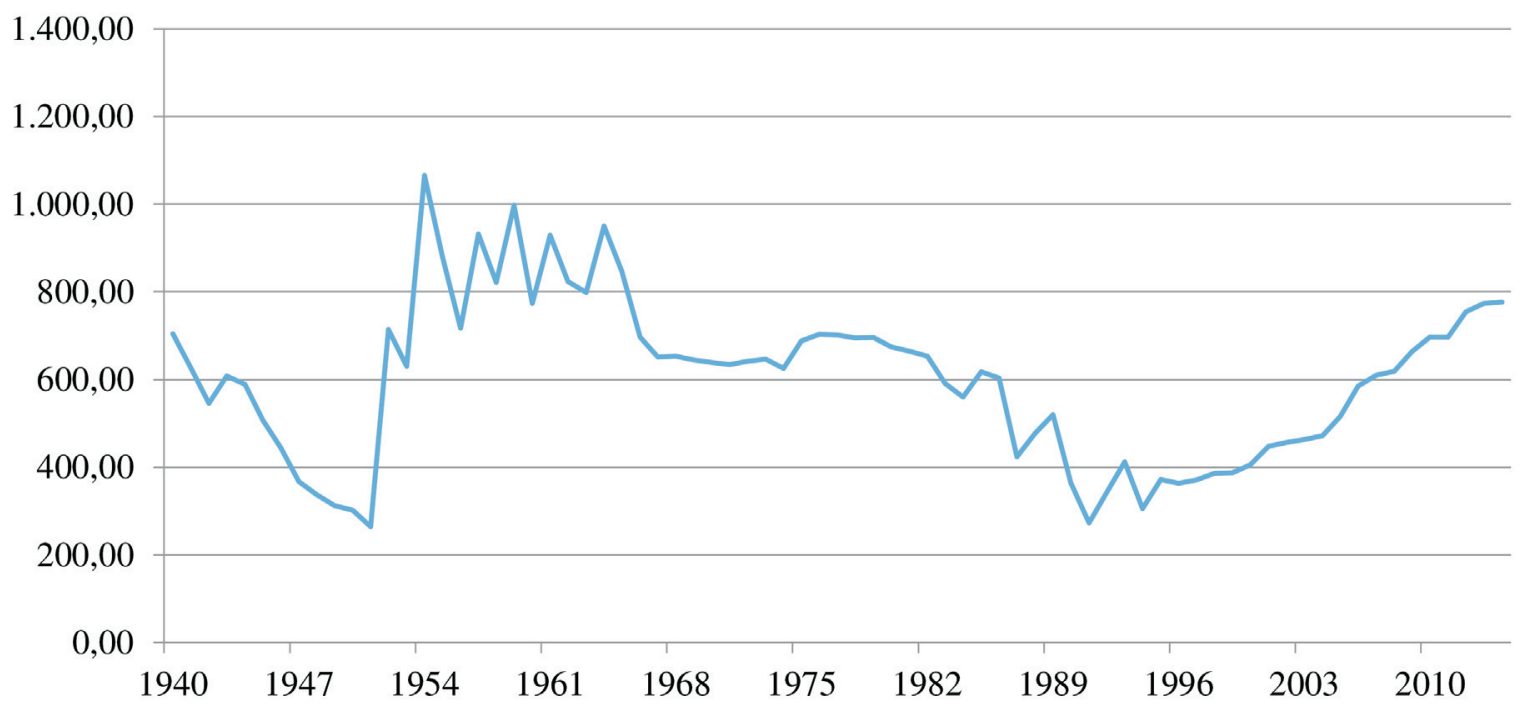

Source: IPEA 2015. 
Table 3 - Periodization, Brazil, Developmentalism

\begin{tabular}{|c|c|c|c|c|}
\hline & $1930-1945$ & $1945-1964$ & 1964-1985/88 & $1980 \mathrm{~s}$ \\
\hline & \multicolumn{2}{|c|}{ 'Populism' } & Military Dictatorship & Democratization \\
\hline Phases & $\begin{array}{l}1^{\text {st }} \text { Vargas government, in- } \\
\text { cluding Estado Novo }\end{array}$ & Democratic 'Populism’ & $\begin{array}{l}\text { 'Milagre Economico' } \\
\text { 1967-1973; 1974/75 - } \\
\text { 1985/88 state-led gradual } \\
\text { opening of the regime }\end{array}$ & $\begin{array}{l}\text { Social movement activism } \\
\text { for Cidadanía resulting in } \\
\text { social reforms (Constitui- } \\
\text { ção Cidadã) against inter- } \\
\text { national 'neoliberal tide' }\end{array}$ \\
\hline $\begin{array}{l}\text { Critical } \\
\text { Junctures }\end{array}$ & $\begin{array}{l}\text { Rising civil society en- } \\
\text { gagement in the cities }\end{array}$ & $\begin{array}{l}1954 \text { suicide of president } \\
\text { Vargas to prevent coup } \\
\text { d'état; } 1960 \text { s inclusion of } \\
\text { hitherto marginalized into } \\
\text { 'populist alliance' }\end{array}$ & $\begin{array}{l}\text { Oil crisis of } 1973 \text { created } \\
\text { economic problems; } 1978 \\
\text { begin of mass strikes in } \\
\text { São Paulo; Debt and infla- } \\
\text { tion crises of } 1980 \text { s }\end{array}$ & $\begin{array}{l}\text { Debt and inflation crises } \\
\text { Resistance by the 'elites' } \\
\text { against social transforma- } \\
\text { tion }\end{array}$ \\
\hline
\end{tabular}

Source: The author.

de Saúde and the further universalization of the Brazilian pension system to include informal agricultural workers (IPEA 2009). Paradoxically, the far reaching social reforms were not accompanied by tax reforms (Oliveira 2010), impeding a thorough universalization of social policies (Santos \& Gentil 2009). The economy continued to be in crisis with hyper-inflation as its most important expression. This can be viewed as an outcome of the correlations of forces: as the claims of workers for higher wages enjoyed high legitimacy, the main reaction of capitalists was to raise prices (Faria 1996). Thereby, class struggle was 'mediated' via inflation and could thereby be discursively transformed into a technical problem, to be solved by competent administration by the state. This can be seen as the beginning of the emergence of a 'discourse of competence' favoring technical solutions to intervene into societal conflicts (Chaui 2000).

\section{Transition to democracy and the current political conjuncture}

As presented in the elaborations above, the South African historical heritage differs from the Brazilian heritage in the important aspect of formalized racism, structuring society for more than 70 years. Contrary to Brazil, where the dominant discourse is rather centered on a 'one-nation project', South African discourse has historically been structured around the idea of a 'two-nations project', albeit with different interpretations. Therefore, the possibilities for constructing a 'general interest' (as the notion of 'hegemony' implies, cf. Gramsci 1971) are much more limited. In contrast, the notion of 'two nations' made it easier for the equality-oriented movements to find common ground, as they could construct a common identity as pertaining to the 'black race' (thereby also deconstructing attempts by the regime to divide the legally disadvantaged groups). Hence, racism could not be mystified as in the case of Brazil and instead became the central target for equality-oriented claims. Furthermore, the historical-institutional heritage of equality-oriented politics practiced by the racist regimes has been marked by ambitious and (concerning the group of the Dutch) successful programs of affirmative action. This heritage is clearly reflected in the current conjuncture concerning equality-related policies (Table 4).

The period following the democratic transition and the landslide victory of the ANC (obtaining $62.6 \%$ of the votes) in the first non-racist general election in 1994, was heavily influenced by the developments in the 1980s and early 1990s: the economic crisis beginning in the 1970s was aggravated by international economic sanctions and the threat that capital could not come back to South Africa or that further capital flight could occur. Furthermore, the high 
Table 4 - Periodization, South Africa, since 1994

\begin{tabular}{|c|c|c|c|}
\hline & $\begin{array}{l}\text { 1994-1998 } \\
\text { Rainbow Nation }\end{array}$ & $\begin{array}{l}\text { 1998-2008 } \\
\text { African Renaissance }\end{array}$ & $\begin{array}{l}\text { Since } 2008 \\
\text { New Africanism/Traditionalism }\end{array}$ \\
\hline Period & $\begin{array}{l}\text { Focus on peace and reconcilia- } \\
\text { tion; avoidance of societal } \\
\text { conflict; 'economic stability' } \\
\text { as Leitmotiv (e.g. GEAR); } \\
\text { Abandoning racist laws, but } \\
\text { little compensation for most } \\
\text { 'formerly disadvantaged' }\end{array}$ & $\begin{array}{l}\text { Post-modern merging of } \\
\text { neoliberalism, leninism and } \\
\text { africanism; Discourse on "two nations" } \\
\text { focuses mostly on race and gives rise } \\
\text { to politics of Affirmative Action }\end{array}$ & $\begin{array}{l}\text { Revival of traditions from the period of } \\
\text { 'the struggle' merge with revival of } \\
\text { African traditionalism; Discursive shift } \\
\text { towards the "developmental state" with } \\
\text { little institutional and material backing }\end{array}$ \\
\hline $\begin{array}{l}\text { Critical } \\
\text { juncture }\end{array}$ & $\begin{array}{l}\text { Lack of improvements for the } \\
\text { majority of the disadvantaged } \\
\text { population }\end{array}$ & $\begin{array}{l}\text { Despite radicalized affirmative action } \\
\text { policies, still lack of improvements for } \\
\text { the majority of the disadvantaged pop- } \\
\text { ulation; rise of social movements; lack } \\
\text { of democracy within the governing al- } \\
\text { liance led to a change in political lead- } \\
\text { ership and discourse }\end{array}$ & $\begin{array}{l}2012 \text { Marikana massacre: despite dis- } \\
\text { cursive shift away from } \\
\text { neoliberalism, still lacking improve- } \\
\text { ments for the majority of the disadvan- } \\
\text { taged population, leading to tensions } \\
\text { related to the issue of class politics, re- } \\
\text { flected within trade union movement } \\
\text { and the governing alliance }\end{array}$ \\
\hline
\end{tabular}

Source: The author.

level of violence fuelled fears that the country could be rendered ungovernable (Marais 2001). With regard to these tendencies, the ANC led a government of 'national unity' together with the adherents of the old regime. Discourse in the period centered on 'peace and reconciliation' and the project of a 'rainbow nation' - the vision of a nation where people could live their racial and ethnic differences in harmony with each other. To sustain this project, the government attempted to introduce the abandoning of racism while avoiding too radical measures that could foster social unrest and economic problems. Therefore, radical transformations occurred in the political and legal spheres, where institutional racism was completely abandoned. Instead, universal social and labor rights were introduced. A good example in the field of social policies is social assistance, which was stratified according to the racial classification of recipients until 1994; 'whites' received much higher benefits than 'blacks'. From 1994 onwards, everybody received equally high benefits. This form of universalization of South African social policies was not accompanied by a substantial amplification of tax collection. Therefore, new measures of 'targeting' had to be applied and paid amounts had to be leveled down closer to the rates formerly paid to 'blacks' (Seekings 2008). Therefore, the fiscal constraint impeded a serious expansion of social policies (Leubolt 2014a).

Due to the negative heritage of apartheid education policies (Giliomee 2009; Mgobozi 2004), equal rights mostly did not translate into better positions for the formerly disadvantaged parts of the population in the labor market, as they were mostly not sufficiently qualified (Buhlungu \& Webster 2006). Apart from the abandoning of explicit racist laws, active interventions into the labor market and the economy were limited. Traditional claims of the freedom movement such as the nationalization of strategic sectors in the economy were dismissed. Instead, concerns about capital flight or its reluctance to invest in South Africa led to a tight framework concerning state spending. Interestingly, neoliberal transformations were even accelerated, when the former apartheid party NP left the 'government of national unity' in 1996 and the GEAR strategy was introduced (Hirsch 2005). Contrary to rhetoric claims, trade liberalization and the tight fiscal framework introduced by GEAR did not make the economy more dynamic and led to further increasing rates of unemployment (Padayachee 2005). For large parts of the formerly disadvantaged groups, the social situation deteriorated or stagnated at the low levels of the apartheid era. This created tensions, 
which began to be prominently addressed by the then-vice president Mbeki in his famous 'two nations speech' in 1998 (Mbeki 1998). In this speech, Mbeki denounced the still existing inequalities between 'whites' and 'blacks' who therefore still rather constituted two nations - the 'white' nation being rich, the 'black' remaining poor (Daniels 2006).

Mbeki's 'two nations discourse' in the year before he was elected as president indicates the attempts of the governing party to sustain the support by their constituencies who were disappointed by the still existing lack of opportunities. The Back Management Forum was a particularly powerful voice of criticism against the dominance of 'whites' in the business sector. In reaction to these criticisms the ANC set up an 'empowerment commission' in 1997, which presented its final report in 2001, which was the basis for the government's strategy of Black Economic Empowerment (BEE, cf. Jack \& Harris 2007). These developments culminated in the government's focus on affirmative action strategies to promote the transformation of racist patterns in economy and society. While beneficial to persons with close ties to the governing alliance of ANC, SACP and Cosatu (Freund 2007), large parts of the formerly disadvantaged continued to be excluded from the benefits of the program. Instead the strong incentives for private companies to employ formerly disadvantaged people at the higher tiers of management started to create tensions concerning the availability of skilled personnel in both the public sector and the partner organizations in government.

Contrary to the developments concerning affirmative action policies, economic policies were only slightly modified. Despite a newly emerging discourse advocating a 'developmental state' (Turok 2008), many pillars of neoliberal economic policies remained untouched (Terreblanche 2009). The dominant discourse of the period can be largely attributed to South Africa's 'first post-modern president' (Marais 2011, p.380) Mbeki, who framed a discourse of 'African Renaissance', which combined traditional African nationalism and post-colonialism with a neoliberal understanding of 'globalization'. Mbeki tended to dismiss critics as people who do not understand the economy sufficiently, which should instead be managed by a finance ministry (Treasury) de-linking itself from political influences of the ANC and its alliance partners and other state apparatuses (Calland 2006). While the equality-oriented policies of this period already were much more successful in promoting some former disadvantaged persons to higher levels in the professional hierarchies in both public and private sectors, the majority of the (predominantly African) poor were not able to improve. This is reflected in the worsening of the intra-racial Gini coefficients among Africans from 0.54 in 1993 to 0.62 in 2008, while the general Gini rose from 0.66 to 0.7 in the same timeframe (Leibbrandt et al., 2010 , p.32). Further rising rates of un- and under-employment led to a further deterioration of income inequalities (SSA 2002; 2008). Social movements grew stronger, fostering more or less radical criticisms on the shortcomings of the government's promises concerning service provision for the formerly disadvantaged groups in society, and most successfully on the government's AIDSdenialism (Marais 2010). As Mbeki's leadership style was also authoritarian and not dialogue-oriented, internal criticism within the government alliance was rising. This set the stage for the dismissal of Mbeki as president of both the ANC and government and created a positive opportunity structure for the rise of a new project (Marais 2011).

Jacob Zuma was the person to profit from the newly created opportunity structures (Pillay 2008; Southall \& Daniel 2009), fashioning a new counter-discourse to the African Renaissance, presenting both elements of continuity and rupture. The new elements concerned the discursive inclusion of important parts of the left, who were given a much stronger voice internally. Official dis- 
course began to be geared towards discursive elements during the times of the struggle against the apartheid regime than the post-modernist discourse popular during the times of Mbeki's presidency. While featuring some socialist elements, the Africanist discourse was also strengthened. The latter discourse has also been reflected in the legal framework - most prominently in the Traditional African Rights Bill, which strengthened the rights of traditional African leaders. This bill has been discussed controversially and criticized for curtailing some of the improvements laid down in the Post-Apartheid constitution, especially concerning gender rights (Marais 2011, p.380ff.). Even some of the aspects of the revival of radical socialist rhetoric have been debated controversially. A prominent example was the discussion between SACP intellectual Jeremy Cronin and (at those times) ANC-Youth League leader Julius Malema on the latter's proposal to nationalize the mines, which was criticized by the former as an attempt to redistribute resources to his close fellows (SAPA 2009). Malema fashioned a radical discourse promoting the interests of 'blacks' by radical reforms, most of the proposals framed within the Africanist discourse. He has been criticized for excessive patronage and promoting a new form of populism going beyond the rhetoric already practiced by Zuma (Preez \& Rossouw 2009). Malema has presented himself as a promising challenger of Zuma by the end of the 2000s, but was finally suspended from the ANC for sowing divisions within the ANC and hate speech in 2011. After that, he founded the party 'Economic Freedom Fighters' to continue promoting his radicalized version of Africanist discourse.

Despite the new discourse featuring a rather post-neoliberal vision for society, it was not capable to result in radical changes concerning the political economy of South Africa (Pons-Vignon \& Segatti 2013). New criticism emerged especially within the labor movement. An important event in this respect was the Marikana massacre in 2012 (Alexander 2013), resulting from strikes of mineworkers and internal divisions in the labor movement. In the end, the police forces shot 34 workers in an operation to end the strike. This has been diagnosed as a clear sign of a 'transition towards violent democracy' (Holdt 2013) and also further contributed to already existing tensions within the labor movement, where a more radical socialist discourse began to emerge. At the end of 2014 , these divisions resulted in the expulsion of the left wing fraction organized in the National Union of Metalworkers of South Africa (NUMSA) from the Confederation of South African Trade Unions (Cosatu). At this point, this can be diagnosed as representing clear signs of a critical juncture. If this will result in radical transformations, it remains to be seen.

\section{Comparing South African to Brazilian developments}

The discourse emerging in the 1990 s concerning economic policies resembled the Brazilian discourse, as both presented economic policies as a matter of applying the right technical solutions. Neoliberalism was presented as the best technical solution to the economic crisis affecting the countries during the 1980s and 1990s, which would safeguard the countries from 'populist solutions' leading to crisis and/or stagnation. Contrary to rhetoric claims, neither economic growth could be substantially boosted, nor did the social situation of the poor and marginalized improve significantly. Instead, unemployment (and/or informality) rates increased substantially and income inequalities stagnated. In both countries, deteriorating working conditions and lacking improvements of the situation of the poor generated new discourses and institutional solutions, which differed substantially from each other: while South Africa was marked by the emergence of an 'anti-racism consensus', an 'anti-poverty consensus' manifested in Brazilian discourse. In Brazil the 'anti-poverty consensus' had different facets since the 1990s. In the mid-1990s, a discourse of 'inclusive liberalism' appeared, emphasizing the limited capacities of the state 
which should therefore be targeted towards the poor, while the better-off should seek for market solutions (Leubolt 2013). This discourse had its heydays by the end of the 1990s and continued to be important until the mid-2000s, albeit with important modifications after the election of Luiz Inácio Lula da Silva (Table 5).

Brazil recorded a more nuanced break with neoliberalism since 2007, when the government introduced 'new developmentalist' policies, building on the historical discourse of progressive developmentalism, which viewed marginalization not only as a moral threat but also as a hindrance to foster economic growth (due to the absence of a mass market capable of consuming the surplus of goods produced in times of high economic growth). This resulted in a discourse of 'inclusive developmentalism' that was institutionalized in both social and economic policies. The ambitious Brazilian Program for Accelerated Economic Growth (PAC) included investments in social infrastructure on a large scale, exemplifying this new approach towards development, linking 'the economic' and 'the social' (Soares 2012). Thus, the Brazilian discourse of 'social developmentalism' did not break with the historical heritage of the 'discourse of competence', but substantially altered it, as investments to counter social inequalities were framed as investments in the economy. Contrary to South Africa, income inequalities recorded a remarkable drop in recent years. Until 2010 , relatively high rates of economic growth indicated success of the strategy of 'growth through redistribution'. With economic growth, the project of redistributing wealth towards the poor was made substantially easier, as the surpluses could primarily be transferred towards the poor without having to be taken away from the better-off. From 2011 onwards, Brazil recorded rather moderate economic growth rates. The financial crisis began to affect the country to a larger extent, as exports to China diminished and the virtuous circle of boosting the economy by enabling the poor to consume was also affected due to increased consumption of imported goods (Sicsú 2013).

In this context, a critical juncture seems to be emerging, as the middle classes have begun to voice protest against the developments described above. The year of 2013 saw mass manifestations on the streets, as Brazilians (mainly from the middle classes) protested during the FIFA events (Singer 2014). The 'anti-poverty consensus' has weakened, especially among the better-off: data

Table 5 - Periodization, Brazil, since 1990

\begin{tabular}{|c|c|c|c|c|}
\hline & \multicolumn{3}{|c|}{ 'Inclusive Liberalism' } & \multirow{2}{*}{$\begin{array}{l}\text { New Developmentalism } \\
2007-2014\end{array}$} \\
\hline & 1990-1994 & 1994-2002 & 2003-2006 & \\
\hline Period & $\begin{array}{l}\text { Neoliberal reforms } \\
\text { (trade) countering } \\
\text { progressive consti- } \\
\text { tution }\end{array}$ & $\begin{array}{l}\text { Neoliberal program of } \\
\text { inflation targeting } \\
\text { (Plano Real) ends infla- } \\
\text { tion; targeting in social } \\
\text { policies; }\end{array}$ & $\begin{array}{l}\text { Continuing inflation tar- } \\
\text { geting; stop privatiza- } \\
\text { tions; less external de- } \\
\text { pendencies; expanding } \\
\text { social transfers (Bolsa } \\
\text { Família); rising mini- } \\
\text { mum wage }\end{array}$ & $\begin{array}{l}\text { Rising state investments in pro- } \\
\text { gressive developmentalist politics } \\
\text { (growth through redistribution); at- } \\
\text { tempts to establish alliance be- } \\
\text { tween national bourgeoisie, work- } \\
\text { ers and marginalized }\end{array}$ \\
\hline $\begin{array}{l}\text { Critical } \\
\text { juncture }\end{array}$ & $\begin{array}{l}\text { Hyper-inflation as } \\
\text { constant symptom } \\
\text { of economic crisis }\end{array}$ & $\begin{array}{l}\text { Financial crises } \\
1998 / 99 \text { and } 2002 \text { re- } \\
\text { sulting in unemploy- } \\
\text { ment and } \\
\text { informalization }\end{array}$ & $\begin{array}{l}\text { Criticism of continuation } \\
\text { of neoliberalism; Lula } \\
\text { wins } 2^{\text {nd }} \text { election despite } \\
\text { 'Mensalão corruption } \\
\text { scandal' }\end{array}$ & $\begin{array}{l}\text { Rising discontent of the upper mid- } \\
\text { dle classes due to relative loss of } \\
\text { status in society (linked to social } \\
\text { uplifting of the poor); Economic } \\
\text { problems, linked to international } \\
\text { conjuncture and problems to form } \\
\text { alliance with national bourgeoisie }\end{array}$ \\
\hline
\end{tabular}

Source: The author. 
${ }^{8}$ Scalon's (2007) definition of 'elites' differs from IPEA's definition, as she identified the $10 \%$ of survey respondents with the highest incomes as 'elites'. for 2010 (IPEA 2011) indicates that only $6.1 \%$ of the Brazilian population view poverty and hunger as the central problem for Brazilian society, and an additional $5.8 \%$ view inequality as the central societal problem. Among the population earning more than five minimum wages (MW), these numbers drop to $3.2 \%$ for inequalities, while poverty and hunger are no longer seen as central problems in this societal group (0\%). Compared to the year 2000, when $11 \%$ of the Brazilian society and $7.6 \%$ of the Brazilian 'elites' ${ }^{8}$ viewed poverty as the central problem (Scalon 2007). Middle class discourse against redistribution is still largely not voiced openly in public but rather channeled into issues compatible with the 'anti-poverty consensus' such as corruption, preventing money to be spent on public services: the access to quality schools ('padrão FIFA') was already among the central demands during the protests of June 2013. Data for 2010 already indicated great differences in the perceptions of the rich (above $5 \mathrm{MW}$ ) and the poor (below MW): While $38.5 \%$ of the rich viewed low quality education or non-access as central cause for poverty and a further $18.5 \%$ saw corruption a major reason, only $15.4 \%$ of the rich saw unemployment as its central reason. Meanwhile, $43.8 \%$ of the poor defined unemployment as central reason and only $11.6 \%$ education, dropping to $9.6 \%$ for corruption. Therefore, important critical voices against the discourse of 'inclusive developmentalism' seem to have emerged among the better-off in Brazil. The political climate before the elections of 2014 was further radicalized. After the very narrow victory of Dilma Rousseff and continuing economic problems, there are signs that the project of 'inclusive developmentalism' might be coming to an end.

\section{Conclusions: possibilities and limits for equality-oriented politics}

The elaborations on discursive and institutional developments regarding equality-oriented politics pointed at the context-dependency of the emergence of such policies. The explicit racism of the South African inequality regime did not only influence institutional developments, but also the equality-oriented discourse emerging within the freedom movement. South African equality-orientation is geared towards anti-racist politics and resulted in the emergence of an 'anti-racism consensus' in the 1990s. The institutionalization of the discourse in policies was furthermore influenced by the policies carried out under the apartheid regime in two important directions. Firstly, apartheid policies were geared at the social uplifting of the Dutch vis á vis the British via affirmative action policies, which could be viewed as archetypical South African equality-oriented policies. Secondly, apartheid education policies for the discriminated parts of the population were geared at producing a cheap low-skilled workforce. This did not only create tensions since the 1970s, when the transformation of the mode of production changed the requirements of the labor market, demanding a higher skilled workforce, but also resulted in problems in the Post-Apartheid era: As there has been a growing importance of affirmative action policies, private companies are heavily incentivized to employ formerly disadvantaged people at all levels, including the middle and higher tiers of management. This resulted in a competition for a high-skilled 'black' workforce which is scarce due to the continuing influence of the apartheid education system. Therefore, capacity problems for both the public sector and the governing tripartite alliance have been created, which are difficult to solve in the short run. These problems are restricting possibilities to invest into social services, which need sufficiently skilled personnel, especially in the field of education policies (Picard 2005; Holdt 2010).

South African opportunity structures opened up possibilities to implement one of the most ambitious affirmative action programs, benefitting not only Africans, but also other formerly discriminated people on the basis of race or gender. This has opened up possibilities for social improvement that are not present 
in the case of Brazil. Contrary to the latter case, South African equality-oriented policies did not succeed in reducing income inequalities, as possibilities for social uplifting are restricted to a rather small group of formerly disadvantaged people who had sufficient access to education and the necessary social capital (links to the governing tripartite alliance) to benefit from the affirmative action program BEE. Critics also point out that the "emergence of a BEE-elite" (Freund 2007) leads to the cooptation of former equality-oriented activists into the inequality regime (Bond 2009). Despite the incorporation of some members of the formerly disadvantaged groups into the upper echelons of society, South Africa largely remains a 'two nations project' where it is difficult to frame an equality-oriented discourse on a common interest.

In contrast, Brazil can resort to historical roots of such an equality-oriented 'one nation discourse', confronting the formal and informal institutional 'twonations project': 'inclusive developmentalism' has historically emerged as such a discourse in the 1950s and has been rearticulated by the government alliance in office until 2014. The strong focus on a 'one nation project' complicates to bring up the issue of inequalities in a more radical way and can also be viewed as the main reason for the reluctance to implement more nuanced anti-racist or gender-related policies. Nevertheless, the success of Brazilian 'inclusive developmentalism' in reducing income inequalities has been remarkable. It remains yet to see if and how the current critical juncture related to lower rates of economic growth and the dropping support by the middle classes can be overcome.

Bernhard Leubolt (Bernhard.leubolt@wu.ac.at) holds a PhD in Political Science from the University of Kassel (Germany) and is Assistant Professor of the Institute of Multi-Level Governance and Development in the Vienna University of Economics and Business. Institutional Affiliation: Vienna University of Economics and Business, Vienna, Austria.

\section{References}

Alexander, N., 2002. An Ordinary Country: Issues in the Transition from Apartheid to Democracy in South Africa. Pietermaritzburg: University of Natal Press.

Alexander, P., 2013. Marikana, Turning Point in South African History. Review of African Political Economy, 40(138), pp.605-619.

Andersen, M.L. \& Hill Collins, P., 2003. Race, Class, and Gender: An Anthology. Belmont: Wadsworth.

Ansell, A.E., 2004. Two Nations of Discourse: Mapping Racial Ideologies in Post-Apartheid South Africa. Politikon, 31(1), pp.3-26.

Beinart, W., 2001. Twentieth-Century South Africa. Oxford: Oxford University Press.

Bond, P., 2009. In Power in Pretoria? New Left Review, 2(58), pp.77-88.

Boyer, R. \& Saillard, Y., eds. 1995. Regulation Theory: The State of the Art. London: Routledge.

Buhlungu, S. \& Webster, E., 2006. Work Restructuring and the Future of Labour in South Africa. In S. Buhlungu; J. Daniel, R. Southall. \& J. Lutchman, eds. State of the Nation: South Africa 2005-2006. Cape Town: HSRC Press.

Calland, R., 2006. Anatomy of South Africa: Who Holds the Power? Cape Town: Zebra Press.

Cardoso, A., 2010. Uma utopia brasileira: Vargas e a construção do estado de bem-estar numa sociedade estruturalmente desigual. Dados, 53(4), pp.775-819.

Cardoso, F.H. \& Faletto, E., 1979. Dependency and Development in Latin America. Berkeley: University of California Press.

Chaui, M., 1995. Cultura política e política cultural. Estudos Avançados, 9(23), pp.71-84. 2000. Cultura e Democracia: o discurso competente e outras falas. São Paulo: Cortez.

Dagnino, E., 1994. Os movimentos sociais e a emergência de uma nova noção de cidadania. In E. Dagnino, ed. Anos 90: Politica e Sociedade no Brasil. São Paulo: Brasiliense.

Daniels, G., 2006. What is the Role of Race in Thabo Mbeki's Discourse? Johannesburg: University of Witwatersrand.

Davies, R.; Kaplan, D.; Morris, M. \& O’Meara, D., 1976. Class Struggle and the Periodisation of the State in South Africa. Review of African Political Economy, 3(7), pp.4-30.

Disraeli, B., 2010. Sybil: Or the Two Nations. Retrieved from http://www.gutenberg.org/files/3760/3760-h/3760-h.htm. Accessed 17 June 2015.

Enriques, P.G., 2007. De la marginalidad a la Exclusión Social: Un mapa para recorrer sus conceptos y núcleos problemáticos. Fundamentos en Humanidades, 8(15), pp.57-88.

Esping-Andersen, G., 1990. The Three Worlds of Welfare Capitalism. Cambridge, UK: Polity Press.

Faoro, R., 2001. Os donos do poder. Formação do patronato político brasileiro. Rio de Janeiro: Globo. 
Faria, L.A.E., 1996. A indústria brasileira em crise: uma abordagem da regulação. Ensaios FEE, 17(2), pp.331-357.

Ferreira, J., ed., 2001. O populismo e sua história: debate e crítica. Rio de Janeiro: Civilização Brasileira.

Ferreira, J. \& Delgado, L.A.N., eds., 2003. O Brasil Republicano 4: O tempo da ditadura - regime militar e movimentos sociais em fins do século $X X$. Rio de Janeiro: Civilização Brasileira.

, eds., 2008. O Brasil Republicano 3: O tempo da experiência democrática - da democratização de 1945 ao golpe civil-militar de 1964. Rio de Janeiro: Civilização Brasileira.

Fiori, J.L., 1995. O vôo da coruja. Uma leitura não-liberal da crise do estado desenvolvimentista. Rio de Janeiro: Editora da UERJ.

Freund, B., 2007. South Africa: The End of Apartheid \& the Emergence of the 'BEE Elite'. Review of African Political Economy, 34(114), pp.661-678.

Freyre, G., 1992. Casa Grande e Senzala. Rio de Janeiro: Record.

Furtado, C., 1963. The Economic Growth of Brazil: A Survey from Colonial to Modern Times. Los Angeles: University of California Press.

2007. Formação Econômica do Brasil. São Paulo: Companhia das Letras.

Gelb, S., 1991. South Africa's Economic Crisis: An Overview. In S. Gelb, ed. South Africa's Economic Crisis. Cape Town: David Philips.

Ghezzi, S. \& Mingione, E., 2007. Embeddedness, Path Dependency and Social Institutions: An Economic Sociology Approach. Current Sociology, 55(1), pp.11-23.

Giliomee, H., 2009. A Note on Bantu Education, 1953 to 1970. South African Journal of Economics, 77(1), pp.190-198.

Gramsci, A., 1971. Selections from the Prison Notebooks. London: Lawrence \& Wishart.

Graser, A., 2009. Políticas orientadas para a igualdade: um novo conceito em Políticas Públicas? Direitos Fundamentais \& Justiça, 3(9), pp.13-37.

Hall, S. \& Gay, P., eds., 1996. Questions of Cultural Identity. London: Sage Publications.

Hamilton, C.V.; Huntley, L.; Alexander, N.; Guimarães, A.S.A. \& James, W., eds. 2001. Beyond Racism: Race and Inequality in Brazil, South Africa, and the United States. Boulder: Lynne Rienner.

Hirsch, A., 2005. Season of Hope. Economic Reform under Mandela and Mbeki. Scottsville: University of KwaZulu-Natal Press.

Holdt, K.v., 2010. The South African Post-Apartheid Bureaucracy: Inner Workings, Contradictory Rationales and the Developmental State. In O. Edigheji, ed. Constructing a Democratic Developmental State in South Africa: Potentials and Challenges. Cape Town: HSRC Press.

2013. South Africa: The Transition to Violent Democracy. Review of African Political Economy, 40(138), pp.589-604.

Jack, V. \& Harris, K., 2007. Broad-Based BEE: The Complete Guide. Northcliff: Frontrunner.

Jessop, B., 2002. The Politics of Representation and the Eighteenth Brumaire. In M. Cowling \& J. Martin, eds. Marx's 'Eighteenth Brumaire': (Post)Modern Interpretations. London: Pluto Press. , 2007. State Power. Cambridge, UK: Polity Press.

Jessop, B.; Bonnett, K.; Bromley, S. \& Ling, T., 1988. Thatcherism: A Tale of Two Nations. Cambridge, UK: Polity Press.

Lamont, M.; Beljean, S. \& Clair, M., 2014. What is Missing? Cultural Processes and Causal Pathways to Inequality. Socio-Economic Review, 12(3), pp.573-608.

Leibbrandt, M.; Woolard, I.; Finn, A. \& Argent, J., 2010. Trends in South African Income Distribution and Poverty since the Fall of Apartheid. OECD Social, Employment and Migration Working Papers, 101.

Leubolt, B., 2009. Correlations of Forces and Policy Outcomes: The Political Economy of Inequality in Brazil and South Africa. In 5th ECPR General Conference. Potsdam. 2013. Institutions, Discourse and Welfare: Brazil as a Distributional Regime. Global Social Policy, 13(1), pp.66-83. 2014a. Social Policies and Redistribution in South Africa. Global Labour University, Working Paper n. 25. Retrieved from http://www.global-labour-university.org/fileadmin/GLU_Working_Papers/GLU_WP_No.25.pdf. Accessed 17 June 2015.

2014b. Social Policies and Redistribution in Brazil. Global Labour University, Working Paper n. 26. Retrieved from http://www.global-labour-university.org/fileadmin/GLU_Working_Papers/GLU_WP_No.26.pdf. Accessed 17 June 2015.

, 2015. Transformation von Ungleichheitsregimes: Gleichheitsorientierte Politik in Brasilien und Südafrika. Wiesbaden: VS Springer.

Lieberman, E.S., 2001. National Political Community and the Politics of Income Taxation in Brazil and South Africa in the Twentieth Century. Politics \& Society, 29(4), pp.515-555.

Louw, P.E., 2004. The Rise, Fall, and Legacy of Apartheid. Westport: Praeger Publications.

Mahoney, J. \& Rueschemeyer, D., eds., 2003. Comparative Historical Analysis in the Social Sciences. Cambridge, UK: Cambridge University Press.

Marais, H., 2001. South Africa: Limits to Change: The Political Economy of Transition. London: Zed. , 2010. The Polarising Impact of South Africa's AIDS Epidemic. In J. Daniel; P. Naidoo, D. Pillay \& R. Southall, eds. New South African Review: 2010: Development or Decline? Johannesburg: Wits University Press. 2011. South Africa Pushed to the Limit: The Political Economy of Change. London: Zed.

Marshall, T.H., 1950. Citizenship and Social Class, and other Essays. Cambridge, UK: Cambridge University Press. 
Marx, A.W., 2006. Making Race and Nation. A Comparison of the United States, South Africa, and Brazil. Cambridge, UK: Cambridge University Press.

Mbeki, T., 1998. Statement of Deputy President Thabo Mbeki at the Opening of the Debate in the National Assembly, on 'Reconciliation and Nation Building'. National Assembly Cape Town, 29 May 1998. Retrieved from http://www.dfa.gov.za/docs/speeches/1998/mbek0529.htm. Accessed 17 June 2015.

Meth, C., 2008. The (Lame) Duck Unchained Tries to Count the Poor. School of Development Studies, University of KwaZulu-Natal, Working Paper n. 49. Retrieved from http://sds.ukzn.ac.za/files/WP\%2049\%20Rev\%20WEB.pdf. Accessed 17 June 2015.

Mgobozi, I., 2004. Human Capital and Credentialism: The Sociological Explanation of Racial Inequalities in South Africa. Current Sociology, 52(5), pp.775-783.

Moulaert, F. \& Jessop, B., 2013. Theoretical Foundations for the Analysis of Socio-Economic Development in Space. In F. Martinelli; F. Moulaert \& A. Novy, eds. Urban and Regional Development Trajectories in Contemporary Capitalism. Abingdon: Routledge.

Nattrass, N. \& Seekings, J., 2001. "Two Nations"? Race and Economic Inequality in South Africa Today. Daedalus, 130(1), pp.45-70.

Novy, A.; Mehmood, A. \& Moulaert, F., 2013. The DEMOLOGOS Methodology for Analysing Urban and Regional Trajectories. In F. Martinelli; F. Moulaert \& A. Novy, eds. Urban and Regional Development Trajectories in Contemporary Capitalism. Abingdon: Routledge.

Oliveira, F.A. 2010. A evolução da estrutura tributária e do fisco brasileiro: 1889-2009. IPEA.Texto para discussão n. 1469. Retrieved from http://www.ipea.gov.br/sites/000/2/publicacoes/tds/td_1469.pdf.

Padayachee, V., 2005. The South African Economy, 1994-2004. Social Research, 72(3), pp.549-580.

Picard, L.A., 2005. The State of the State: Institutional Transformation, Capacity and Political Change in South Africa. Johannesburg: Wits University Press.

Pillay, D., 2008. COSATU, the SACP and the ANC post-Polokwane: Looking Left but does it Feel Right? Labour, Capital and Society, 41(2), pp.5-37.

Pons-Vignon, N. \& Segatti, A., 2013. 'The Art of Neoliberalism': Accumulation, Institutional Change and Social Order since the End of Apartheid. Review of African Political Economy, 40(138), pp.507-518.

Poulantzas, N., 1974. Fascisme et dictature. Paris: Éditions du Seuil/Maspero.

Preez, M.D. \& Rossouw, M., 2009. The World According to Julius Malema. Cape Town: Kwela.

Santos, C.H. \& Gentil, D.L., 2009. A CF/88 e as finanças públicas brasileiras. In J.C. Cardoso Jr., ed. A Constituição brasileira de 1988 revisitada: recuperação histórica e desafios atuais das políticas públicas nas áreas econômica e social. V. 1 Brasília: IPEA.

Scalon, C., 2007. Justiça como igualdade? A percepção da elite e do povo brasileiro. Sociologias, 18, pp.126-149.

Seekings, J., 2008. Deserving Individuals and Groups: The Post-Apartheid State's Justification of the Shape of South Africa's System of Social Assistance. Transformation, 68, pp.28-52.

Seekings, J. \& Nattrass, N., 2005. Class, Race, and Inequality in South Africa. New Haven: Yale University Press.

Singer, A., 2014. Rebellion in Brazil. New Left Review, 2(85), pp.19-37.

Soares, L.T., 2012. Transformaciones recientes en las políticas sociales y efectos sobre la estructura social en América Latina. In I. Lesay, \& B. Leubolt, eds. Lateinamerika nach der Krise: Entwicklungsmodelle und Verteilungsfragen. Wien: LIT.

Southall, R. \& Daniel, J., eds., 2009. Zumani! The 2009 South African Elections. Auckland Park: Jacana.

Souza, H.J., 2002. Como se faz análise de conjuntura. Petrópolis: Vozes.

Stewart, F., 2002. Horizontal Inequalities: A Neglected Dimension of Development. QEH Working Papers, 81. Retrieved from: http://www3.qeh.ox.ac.uk/RePEc/qeh/qehwps/qehwps81.pdf. Accessed 8 Jun 2015.

Tavares, M.C., 2000. Auge e declínio do processo de substituição de importações no Brasil. In R. Bielschowsky, ed. Cinquenta anos de pensamento na CEPAL. Rio de Janeiro: Record.

Terreblanche, S., 2002. A History of Inequality in South Africa, 1652-2002. Scottsville: University of Natal Press. , 2009. The Developmental State in South Africa: The Difficult Road Ahead. In P. Kagwanja \& K. Kondlo, eds. State of the Nation: South Africa 2008. Cape Town: HSRC Press.

Turok, B., ed., 2008. Wealth Doesn't Trickle Down: The Case For a Developmental State in South Africa. Cape Town: New Agenda.

Walby, S., 2009. Globalization \& Inequalities: Complexity and Contested Modernities. London: Sage Publications.

Weber, M., 1980. Wirtschaft und Gesellschaft. Grundriß der Verstehenden Soziologie. Tübingen: Mohr Siebeck.

Weffort, F., 1978. O populismo na política brasileira. Rio de Janeiro: Paz e Terra.

Wolpe, H., 1980. Capitalism and Cheap Labour-Power in South Africa: From Segregation to Apartheid. In H. Wolpe, ed. The Articulation of Modes of Production: Essays from Economy and Society. London: Routledge. 1990. Race, Class \& the Apartheid State. Trenton: Africa World Press.

\section{Newspaper articles}

Sicsú, J., 2013. Ideia de 'governar para todos’ está esgotada: Os novos tempos exigem uma economia política que tenha lado. O lado da classe trabalhadora. Carta Capital, 16 July 2013. Retrieved from 
http://www.cartacapital.com.br/economia/ideia-de-governar-para-todos-esta-esgotada-8125.html. Accessed 16 June 2015.

\section{Other sources}

IPEA, 2015. Políticas Sociais - Acompanhamento e Análise. Boletim 17: Volume 1. Brasília: IPEA. Retrieved from http://www.ipea.gov.br/sites/000/2/politicasocial/html/pdf/Volume_1.pdf. Accessed 16 June 2015.

,2011. Assistência Social. Percepção sobre pobreza: causas e soluções. Sistema de Indicadores de Percepção Social. Retrieved from http://www.ipea.gov.br/portal/images/stories/PDFs/SIPS/111221_sips_assistenciasocial.pdf. 2015. Ipea data. Retrieved from: www.ipeadata.gov.br. Accessed 17 June 2015.

SAPA, 2009. Malema, Cronin Scrap Over Mine Nationalisation. Mail \& Guardian, 21 Nov. Retrieved from http://mg.co.za/article/2009-11-21-malema-cronin-scrap-over-mine-nationalisation.

SSA, 2002. Earning and spending in South Africa: Selected findings and comparisons from the income and expenditure surveys of October 1995 and October 2000. Pretoria: Statistics South Africa. Retrieved from: http://www.statssa.gov.za/publications/earningspending2000/earningspending2000October2000.pdf. Accessed 8 Jun 2015.

, 2008. Income and expenditure of households 2005/2006. Pretoria: Statistics South Africa. Retrieved from http://www.statssa.gov.za/publications/P0100/P01002005.pdf. ,2014. Poverty Trends in South Africa: An examination of absolute poverty between 2006 and 2011. Pretoria: Statistics South Africa. Retrieved from: http://beta2.statssa.gov.za/publications/Report-03-10-06/Report-03-10-06March2014.pdf. Accessed 8 Jun 2015.

\section{Resumo}

O artigo foca a produção e reprodução das desigualdades sociais no Brasil e na África do Sul. O objetivo é interligar diferentes perspectivas teóricas e aplicá-las a uma análise comparativa das políticas relacionadas à desigualdade. Lançando mão do institucionalismo estratégico-relacional, são analisadas a herança histórica da formação discursiva e a institucionalização dos regimes de desigualdade nos dois países, de modo a informar a análise da conjuntura mais recente. Enquanto a África do Sul é um exemplo de discriminação racista formal, o regime de desigualdade do Brasil funcionou baseado em padrões mais informais. As heranças históricas distintas influenciam o foco atual das políticas relacionadas à igualdade, as quais tendem a ser predominantemente anti-racistas na África do Sul, enquanto no Brasil o foco foi reduzir da pobreza. A experiência brasileira tendeu mais ao discurso de um "interesse comum" e foi mais capaz de institucionalizar as políticas para a redução das desigualdades de renda. A África do Sul ainda é discursivamente dividida em "duas nações". A ascensão social para os africanos ligados aos partidos governistas foi apenas parcialmente acompanhada por melhores condições de vida para a maioria pobre dos africanos. Ambos os países são significativamente estruturados pelas respectivas heranças históricas no que diz respeito tanto à criação como à redução das desigualdades. O discurso de "uma nação" no Brasil foi mais bem sucedido em promover políticas relacionadas à igualdade em comparação com o discurso de "duas nações" da África do Sul. A despeito de melhorias importantes, ambos os países se encontram atualmente em conjunturas críticas e as contradições societais estão começando a criar novas tendências de crise.

PALAVRAS-CHAVE: Brasil; África do Sul; desigualdade; institucionalismo histórico; políticas sociais.

License information: This is an open-access article distributed under the terms of the Creative Commons Attribution License (CC-BY-NC 4.0), which permits unrestricted use, distribution, and reproduction in any medium, provided the original work is properly cited. 